\title{
John F. Kennedy's back: chronic pain, failed surgeries, and the story of its effects on his life and death
}

\author{
T. Glenn Pait, MD, and Justin T. Dowdy, MD \\ Department of Neurological Surgery, Jackson T. Stephens Spine and Neurosciences Institute, University of Arkansas for Medical \\ Sciences, Little Rock, Arkansas \\ The 35th president of the United States, John F. Kennedy (JFK), experienced chronic back pain beginning in his early \\ 20 s. He underwent a total of 4 back operations, including a discectomy, an instrumentation and fusion, and 2 relatively \\ minor surgeries that failed to significantly improve his pain. The authors examined the nature and etiology of JFK's back \\ pain and performed a detailed investigation into the former president's numerous medical evaluations and treatment \\ modalities. This information may lead to a better understanding of the profound effects that JFK's chronic back pain and \\ its treatment had on his life and presidency, and even his death.
}

https://thejns.org/doi/abs/10.3171/2017.2.SPINE151524

KEY WORDS JFK; John F. Kennedy; failed back surgery; Wilson plate; history; President Kennedy assassination

$\mathbf{J}$ OHN Fitzgerald Kennedy (JFK), the 35th president of the United States and the youngest candidate elected to the Oval Office, was portrayed as a dynamic man full of vigor and youthful energy. ${ }^{61}$ This aura of vitality belied the fact that he was patently unhealthy from an early age. ${ }^{14,57}$ The full extent of his wide array of medical problems, especially relating to his time in the Oval Office, remained a secret as directed by the Kennedy family until 2001. ${ }^{1}$ Low-back pain, just one of Kennedy's many medical problems, prompted a total of 4 largely unsuccessful surgeries. This pain affected him nearly continually from his undergraduate years at Harvard until the day of his assassination.

\section{A Childhood of Poor Health: Numerous IIInesses and Hospitalizations}

John Fitzgerald Kennedy was born the second of 8 children to Joseph P. Kennedy Sr. and Rose Fitzgerald Kennedy in Brookline, Massachusetts, on May 29, 1917. Several months shy of his 3rd birthday, young "Jack" contracted scarlet fever and was hospitalized; his condition ultimately deteriorated to the brink of death. ${ }^{14,31,33,57,62}$ His childhood health troubles continued; he would be treated for a host of illnesses prior to his graduation from prepara- tory school. 1,14,21,24,57 In fact, Robert F. Kennedy would later recall that "when we were growing up together we used to laugh about the great risk a mosquito took in biting Jack Kennedy-with some of his blood the mosquito was almost sure to die." ${ }^{51}$

\section{Collegiate Years: Origins of Low-Back Pain and First Consultation}

Jack would add yet another entry to an already prodigious list of health problems during his undergraduate years at Harvard: low-back pain. The exact details of the inciting event remain murky, but the most commonly accepted account traces the onset of low-back pain to a football injury he sustained while at Harvard in 1937. 2,5,21,26,29,32,33,57

Kennedy continued to be plagued with back pain after graduating from Harvard University in June 1940 and was referred to Dr. Gilbert "Ned" Haggart, an orthopedic spine specialist at the Lahey Clinic in Boston, who diagnosed him with a "very unstable lumbosacral joint." Dr. Haggart recommended a course of conservative treatment in the form of a manipulation of the back under anesthesia, which JFK underwent at the Lahey Clinic in 1940. Dr. Haggart also introduced the idea of a sacroiliac fusion if the conservative treatment failed. ${ }^{22,23,29}$ 
John F. Kennedy's back pain would begin to play a central role in his overall health going forward. Immediately, it would affect his prospects for military service.

\section{0-1943: Failed Military Physicals and the PT-109}

On October 29, 1940, John Kennedy, age 23 years and the son of the US ambassador to Great Britain, was drafted for service in the US military..$^{70}$ Although selected, his student status at Stanford qualified him for an automatic deferment. ${ }^{14,66} \mathrm{He}$ then tried to enlist in the Army but was rejected due to health issues, particularly his bad back. He then applied to the Navy Officer Candidate School in 1941, but failed the physical. ${ }^{14,24}$ Ultimately, via the connections of his ex-ambassador father, JFK was commissioned as an ensign in the US Naval Reserve on September 25, 1941. ${ }^{28}$

Within months, Kennedy's back troubles would prompt further consultations-Dr. Marius Smith-Petersen concluded: "I don't think this is a disc since the pain complained of does not even remotely resemble a disc." ${ }^{26,29}$ Dr. Smith-Petersen requested that JFK also consult with Dr. James White, a naval neurosurgeon who agreed that Kennedy's current pain was inconsistent with sciatica. ${ }^{29}$ The decision was made against surgical intervention. By late June 1942, Ensign Kennedy was declared fit for duty. ${ }^{14,29,55}$

Kennedy then applied for and was accepted into midshipman school in the spring of 1942 with his eye on active sea duty. ${ }^{29} \mathrm{He}$ ultimately was accepted to patrol torpedo (PT) boat training school. Kennedy, who just several months before had been hospitalized for his back issues, would again need intercession from his father to gain acceptance to the highly competitive PT boat training program. Despite his back pain, Kennedy completed PT boat training and was ultimately ordered to the Pacific theater on January $8,1943 .^{25}$

Within months of arriving in the Pacific, Kennedy's boat was rammed by a Japanese destroyer, killing 2 crew members and stranding Kennedy and his surviving shipmates, marking the beginning of the famous PT-109 episode in which Kennedy towed a badly wounded crewman with the strap of his life jacket clenched between his teeth for a punishing 5-hour swim to a nearby island. The survivors were eventually rescued and Kennedy would serve another 6 weeks before ending his Pacific tour of duty on November $18,1943.5,14,15,24,50,51$

\section{June 23, 1944: The First Back Surgery}

Surviving the collision with the Japanese destroyer and enduring the grueling nature of the subsequent rescue worsened JFK's back problems. ${ }^{5}$ Therefore, once he returned stateside, he was evaluated by a team of physicians at the Mayo Clinic, including noted orthopedist Dr. Ralph Gormley, who summarized Lt. Kennedy's condition at that time as "confined ... to the region of the left sacroiliac with pain in the posterior part of the left hip down as far as the knee." $15,18,19,29$

Given that Kennedy's presentation was not an obvious one for a herniated disc, he underwent an air myelogram and the Mayo team stated that "a diagnosis of a protruded disk was not definite ... at this time you are not in need of surgery." 31

Kennedy eventually proceeded with surgery. He was admitted to New England Baptist Hospital and on June 23 he underwent a left L4-5 laminotomy and L5-S1 discectomy performed by Dr. James Poppen, neurosurgeon at the Lahey Clinic ${ }^{16,29}$ (Fig. 1). JFK initially did well for 2 weeks postoperatively, before the onset of severe muscle spasms on an attempt to ambulate. At 6 weeks postoperatively, Poppen wrote:

On June twenty-third I did a unilateral exploration of the fourth and fifth lumbar interspaces. The fourth space was completely normal. However, the nerve in the fifth interspace was reddened and underlying this, the disk interspace material was abnormally soft and the posterior longitudinal ligament was firmly adherent to the nerve root. There, however, was very little protrusion of the ruptured cartilage. A thorough removal of the degenerative portion of the cartilage was carried out.... The patient did well following the operation for a period of two weeks. Upon having the patient get up and about, however, severe muscle spasms in the low back took place. These necessitated fairly large doses of narcotics to keep him comfortable.... I have had nine other patients in a series of over five hundred ruptured intervertebral disks with a similar experience.... I am indeed sorry that this had to happen with Lieutenant Kennedy. ${ }^{29}$

Kennedy was subsequently transferred to the Chelsea Naval Hospital for recovery and another evaluation by Dr. James White, the same neurosurgeon who had seen him at the request of Dr. Smith-Petersen before JFK's assignment in the Pacific. Dr. White described Kennedy as "obviously incapacitated by pain in low back and down the left leg" and questioned the indication for the lumbar surgery because air was the agent used for the myelogram and not Pantopaque. 26,29

At this time, myelography was performed with gas, air, or oxygen, or with agents such as iodinated lipoid or iodine salts. Controversy surrounded the respective merits of the available agents: Pantopaque uptake provided excellent evidence of the subarachnoid space and the nerve root sheath; however, this process was not without complications-including oil granulomas and arachnoiditis from the residual contrast material. Air, on the other hand, could be used without such risks. It absorbed quickly and had no lasting effects on the membranes of the spinal cord. ${ }^{71}$ Perhaps due to Jack Kennedy's prominent status as a war hero and the son of Joseph Kennedy, air was the agent chosen for the myelogram instead of a potentially more accurate and risky study performed with Pantopaque.

Although his preoperative air spinogram is not housed at the JFK Presidential Library and thus is not available for review, we were able to review preoperative lumbar radiographs dated May 20, 1942, in addition to postoperative films dated December 14, 1944. These demonstrate a normal lumbar lordotic curve with well-aligned facet joints and no evidence of spondylolisthesis or discernible sacroiliac disease. There was no evidence for loss of vertebral body or interspace height, and no obvious radiographic laminotomy defects or other abnormalities evident on the postoperative films - essentially JFK had a radiographically normal-appearing lumbar spine in December 1944.

Kennedy, no doubt disappointed in the results of the 


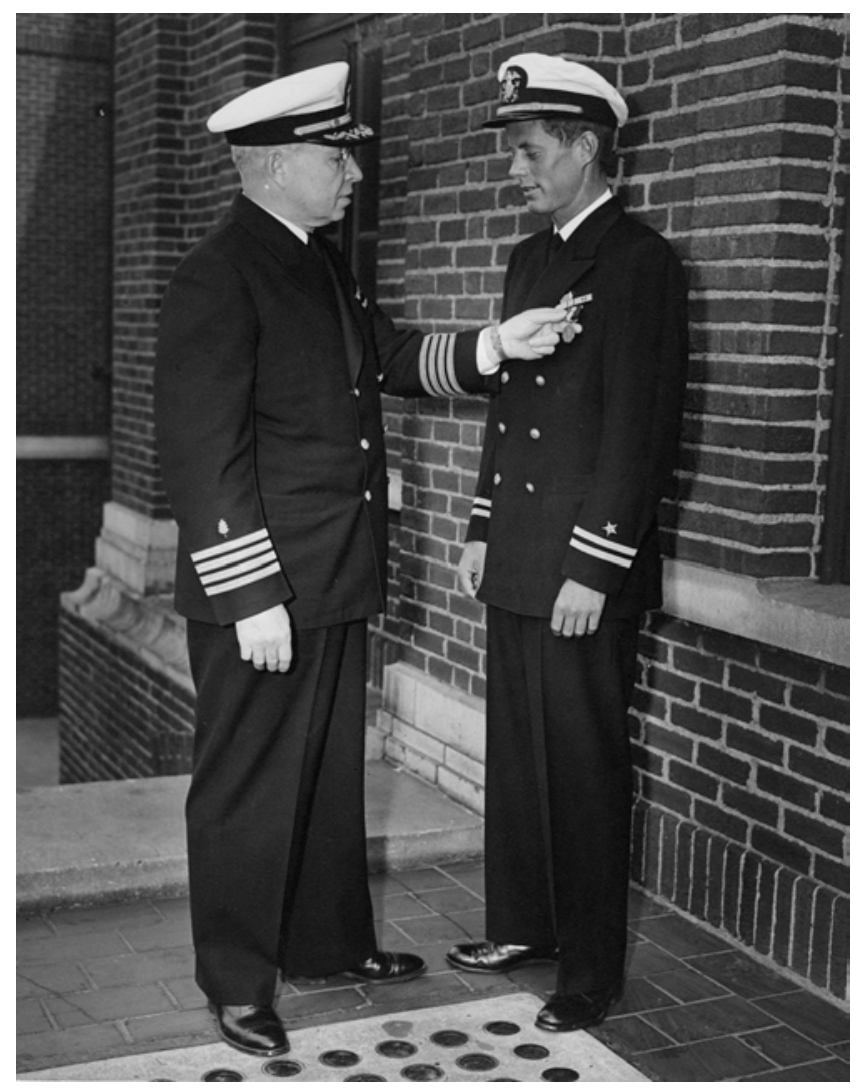

FIG. 1. Lieutenant John F. Kennedy is awarded the Navy and Marine Corps medal on June 12, 1944, by Captain Frederick L. Conklin for his actions in the PT-109 episode. Incidentally, the medal was presented to JFK at the Chelsea Naval Hospital in Massachusetts on the day of his admission in preparation for the subsequent L5-S1 discectomy procedure by Dr. Poppen at New England Baptist Hospital 11 days later. Photo is in the public domain, and was supplied courtesy of the John F. Kennedy Presidential Library and Museum, Boston, Massachusetts.

surgery, wrote: "In regard to the fascinating subject of my operation ... I think the doc should have read just one more book before picking up the saw." 24,65

While recovering at Chelsea Naval Hospital in the fall of 1944, Jack received word that his older brother Joe had been killed in action in England. ${ }^{24}$ Late in 1944, JFK's back troubles eventually eased up although his gastrointestinal difficulties continued-prompting the Navy to declare him permanently unfit for service on November 25, 1944. JFK was back in the civilian sector, now the heir to the family political aspirations once cast upon his late brother.

\section{Congressional Years: Continued Back Pain and Diagnosis of Addison's Disease}

In April 1946, JFK declared his candidacy for the US House of Representatives, Massachusetts 11th district. The next several months of campaigning exhausted the 29-year-old Kennedy-described by a campaign worker as "crippled." His back pain returned, and care of his back required a daily regimen of therapy involving back rubs,

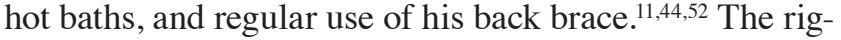
ors of campaigning took their toll, culminating with JFK's collapse while marching in a parade on June 17, 1946, less than 24 hours before the election. ${ }^{5}$ Nonetheless, the following day JFK was elected to Congress, nearly 2 years after his failed discectomy surgery..$^{24,44}$

Kennedy's first term in Congress would be marred by health difficulties, with a particularly grave event occurring in his 1st year in office during a trip to England. In an effort to treat his long-standing gastrointestinal disease, Kennedy probably began taking corticosteroids in the late 1930 s or early 1940 s via subcutaneously implanted corticosteroid tablets that became available in $1937 . .^{14,72} \mathrm{His}$ insouciant attitude toward medications led to an abrupt cessation of steroid intake and precipitated a severe adrenal crisis in 1947 during an overseas trip to London. Kennedy became severely ill, requiring hospitalization in London, and was eventually diagnosed with Addison's diseaseprobably secondary to chronic steroid intake. The situation was so dire, in fact, that he was read his last rites of the Catholic Church upon his arrival stateside..$^{14}$

Despite his ongoing health problems, Kennedy's service in the House of Representatives over the next few years crystallized his desire to advance his political career. To bolster his statewide profile, Congressman Kennedy began crisscrossing Massachusetts, usually beginning at dawn and ending after midnight-an intense schedule likely to be unforgiving to his back..$^{14}$ Dave Powers, his longtime political advisor, stated that Kennedy had to travel "with crutches ... gritting his teeth when he walked ... but then when he came into the room where the crowd was gathered, he was erect and smiling, looking as fit and healthy as the light-heavyweight champion of the world. Then after he finished his speech and answered questions from the floor and shook hands with everyone, we would help him into the car and he would lean back on the seat and close his eyes in pain." ${ }^{20,56}$ The grueling schedule and work paid off; after 7 years in the House of Representatives Kennedy was elected to the US Senate in 1952.

\section{The Senate Years: Second Back Surgery- Lumbosacral Instrumentation and Fusion With Dr. Philip Wilson Sr.}

Kennedy's back troubles progressed further during his Senate years and he required the near-constant use of crutches by the spring of $1954 . .^{20,28,47,49,56}$ After evaluations at the Lahey Clinic, Bethesda Naval Hospital, and Hospital for Special Surgery in 1954, Senator Kennedy decided to proceed with a lumbosacral fusion operation despite the high risk of complications or death in the context of his Addison's disease. ${ }^{63}$ Rose Kennedy would later remember, "Jack was determined to have the operation. He told his father that even if the risks were fifty-fifty, he would rather be dead than spend the rest of his life hobbling on crutches and paralyzed by pain." 21

Kennedy's anteroposterior and lateral lumbosacral radiographs from January 1954, which we viewed at the JFK Presidential Library and Museum, demonstrate marked loss of height at the previously surgically treated L5-S1 disc space (approximately 70\%) when we compared it with the most recent previous film from 1944. There is no evidence of compression fractures as has been reported 


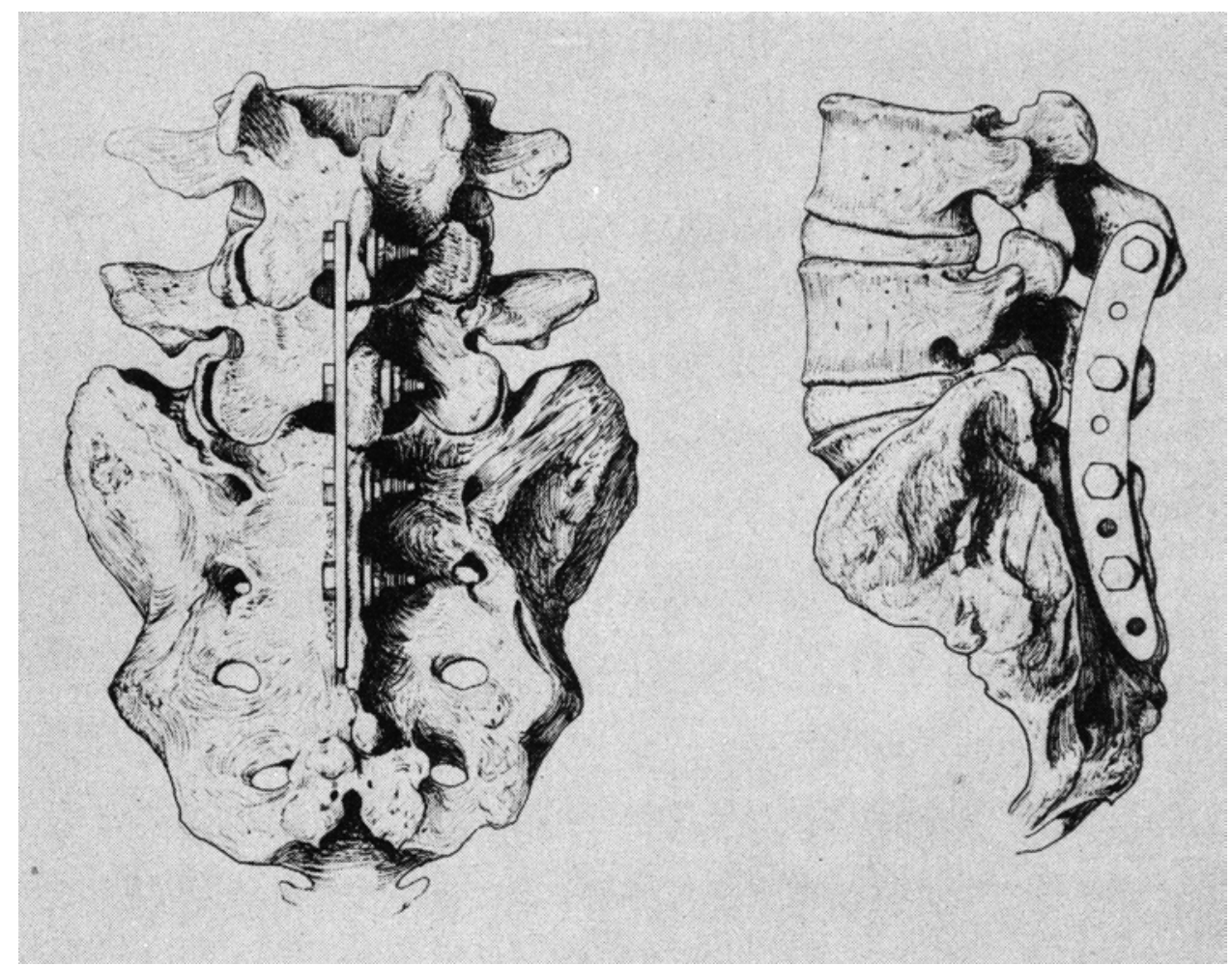

FIG. 2. Illustration depicting the proper placement of the Wilson plate in situ. Note the horizontally oriented transverse bolts placed through the spinous processes and secured in place with locking nuts. The plate was also often augmented with wire fixation, as it was in Kennedy's case. Reprinted with permission from: Wilson PD, Straub LR: Lumbosacral Fusion with Metallic-Plate Fixation, in Pease CN (ed): Instructional Course Lectures Volume IX. Rosemont, IL, American Academy of Orthopedic Surgeons, 1952, pp 53-57.

by historian Robert Dallek in his 2003 bestselling JFK biography. ${ }^{14}$

Senator Kennedy was admitted to the Hospital for Special Surgery, New York, on October 10, 1954. After several weeks of preoperative optimization to reduce the risk of a potentially fatal adrenal crisis related to his Addison's Disease, he underwent a 3-hour procedure for sacroiliac and lumbosacral fusion on October 21, 1954, with implantation of a Wilson plate by the physician who developed the plate, Dr. Philip Wilson Sr., a renowned orthopedic surgeon and a Harvard classmate of JFK's father. $28,43,53,57,60$

The Wilson plate was a Vitallium (cobalt-chromium alloy) implant that was curved to mimic lumbar lordosis and secured to the spinous processes with horizontally oriented locking bolts (Figs. 2 and 3) in a procedure first described by Dr. Wilson in May 1943. ${ }^{12,26,73}$

Postoperative radiographs dated November 12, 1954, demonstrated Kennedy's implant spanning L5-S2 via 3 transverse bolts attached to the spinous processes on the right side and augmented with a wire at the L-5 spinous process, along with a defect at the left sacroiliac joint consistent with bone graft placement for sacroiliac arthrodesis.

\section{Winter and Spring of 1954-1955: \\ A Complicated Recovery and an "Open, Gaping, Very Sickly Looking Hole"}

Although we could not locate his records from the

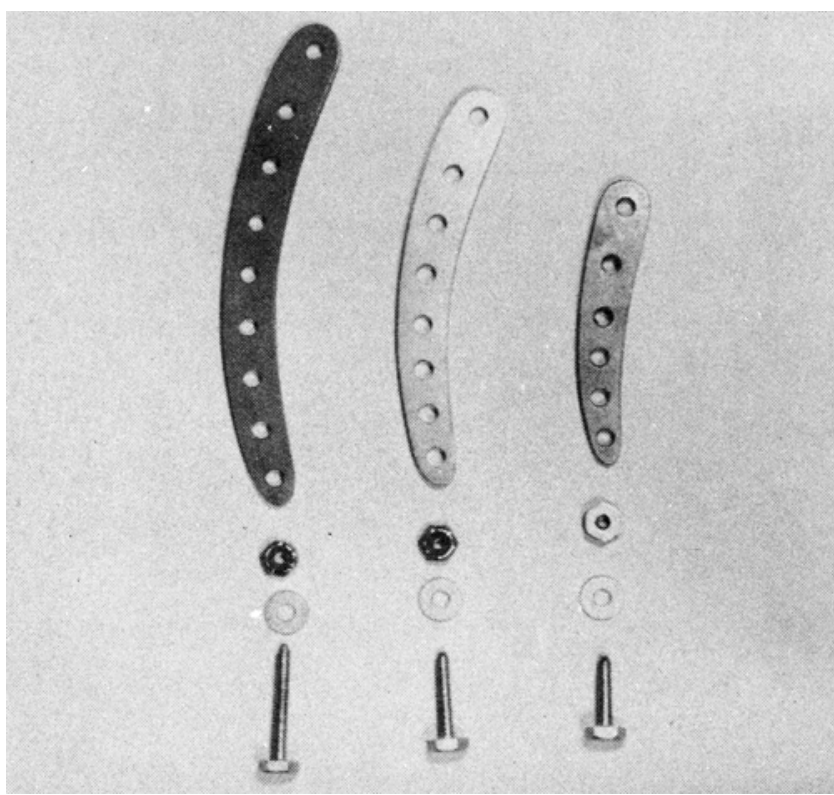

FIG. 3. Photograph showing the components of the Wilson plate used in JFK's 1954 instrumentation operation. Reprinted with permission from: Wilson PD, Straub LR: Lumbosacral Fusion with Metallic-Plate Fixation, in Pease CN (ed): Instructional Course Lectures Volume IX. Rosemont, IL, American Academy of Orthopedic Surgeons, 1952, pp 53-57. 
Hospital for Special Surgery, Kennedy's surgery and postoperative course were published anonymously by his surgical team as Case 3 in a 1955 case series documenting survivors and perioperative management in patients with adrenocortical insufficiency. ${ }^{53}$ His postoperative course was described as "satisfactory in that no Addisonian crisis developed" and he experienced "minor complications, consisting of a urinary tract infection on the third postoperative day, a transfusion reaction ... and a mild wound infection despite antibiotic therapy." The paper's brief description of his postoperative course in fact greatly minimized his difficult recovery-the urinary tract infection was so severe it precipitated a coma, and the family, anticipating death, rushed to Jack's side where he was again read his last rites. ${ }^{47,57}$ However, he eventually improved and was discharged from the hospital to continue his recovery in Palm Beach, Florida, on December 21, 1954-exactly 2 months after his surgery. ${ }^{57}$

His recovery in Palm Beach would continue to be complicated by a "staphylococcal infection" 69 and was described by Ted Sorenson, a longtime advisor and friend, as an "open, gaping, very sickly looking hole." ${ }^{65,69}$ LeMoyne Billings, another JFK confidant who visited him during this time, would later state "the area where they cut into his back never healed. It was oozing blood and pus all the time. It must have been painful beyond belief.... It was an open wound that seemed to be infected all the time. And now and then a piece of bone would come out of the wound. His pain was excruciating." 59

When it became apparent that the open draining wound was infected and not healing, Kennedy returned to the Hospital for Special Surgery for his third back operation, consisting of hardware explantation, on February 10, $1955.53,57$

Senator Kennedy's lumbar radiographs dated April 27, 1955-housed at the JFK Library and reviewed by usshow no changes (aside from interval implant removal) in comparison with the January 5, 1955, films. Joe Kennedy would reflect on his son's recovery from these operations by reporting that he twice came within minutes of dying, leading some to speculate that he was twice read his last rites during this period. ${ }^{17,20,49,57}$ Kennedy's 1954 surgery and the subsequent life-threatening complications would require months of recovery, preventing him from returning to the Senate until May of 1955-at which time the incision from his February hardware removal had only recently healed. ${ }^{57,69}$

In 1955, Kennedy was introduced to Dr. Janet Travell, a Cornell University pharmacologist and internal medicine specialist known for her work using trigger-point injections of local anesthetics to treat myofascial pain. Dr. Travell promptly admitted Senator Kennedy to the New York Hospital-Cornell Medical Center to jump-start his rehabilitation program. ${ }^{64,69}$ Kennedy, who celebrated his 38th birthday during this hospitalization, was treated with ethyl chloride spray and procaine trigger-point injections.

This hospitalization marked the first of hundreds, if not thousands, of procaine trigger-point injections he would receive over his lifetime and introduced Kennedy to what would, in a few short years, become a symbol of his presidency - the rocking chair. ${ }^{69}$ More importantly, it marks the end of his major back surgeries and a shift in focus toward muscular and environmental factors contributing to his back pain. The emphasis regarding treatment of his back would move in a more cautious direction going forward, and notable functional restoration would be seen over the next few months. ${ }^{69}$

\section{The Late 1950s: Kennedy's Last and Most Uncomplicated Back Surgery}

In addition to the rocking chair, Travell made other changes, including providing Kennedy with a heel liftraising the possibility of pelvic obliquity and leg-length discrepancy as a contributing factor in Kennedy's lowback pain. These changes, combined with procaine injections and a muscle-strengthening program, led to significant improvement in JFK's low-back health and overall functioning during this time. His back surgeries, however, were not completely behind him; in September 1957 "a painful point of redness appeared in the midline operative scar of the lumbar spine fusion." ${ }^{70} \mathrm{He}$ was diagnosed with a superficial lumbar abscess, and admitted again to the Hospital for Special Surgery on September 13, 1957. Preston Wade, a general surgeon, opened the abscess down to the spinal processes of L-4 and L-5 - a markedly less invasive surgery than the senator's first 3 operations. Cultures grew coagulase-positive Staphylococcus aureus $^{69}$-approximately 3 years after JFK's October 1954 fusion procedure.

According to Travell, radiographs of the lumbosacral spine and pelvis obtained on September 13, 1957,

\section{... showed variation in the density of the left sacral wing compatible with chronic osteomyelitis. Repeat films of the lumbosacral spine on 09/20/57 showed degeneration of the lumbosacral disk with inflammatory process near the left sacroiliac joint, possibly due to osteomyelitis. The patient continued to do well, except for occasional muscle spasms which were relieved by procaine infiltration. Full ambulation was begun and the patient was discharged after 19 days of hospitalization.}

In our opinion, the radiographic abnormalities Dr. Travell is referring to in the left sacroiliac region are more consistent with the postoperative changes from the sacroiliac arthrodesis performed during the fusion procedure.

The next few years would be a period of relatively good health for Kennedy, and were punctuated by his 1958 Senate reelection in which he received $73.6 \%$ of the popular vote, the largest margin of victory ever recorded in a Massachusetts Senate race..$^{14} \mathrm{His}$ ascendant national profile put him squarely in the race as the Democratic nominee for the presidential election in 1960 - a race that would publicize concerns regarding his health on the national stage.

\section{The 1960 Election and 1961: "Dr. Feelgood's" Methamphetamine Injections and a Relapse of Back Pain}

Days before the Democratic National Convention opened on July 11, 1960, JFK's opponent for the Democratic nomination and soon-to-be running mate, Lyndon Johnson, raised serious doubts about Kennedy's health- 
publicly divulging the Addison's diagnosis and asking for an evaluation of his overall health. ${ }^{14}$ Although his back was in comparatively decent shape, the 1960 campaign took its toll, prompting Kennedy to seek the services of Dr. Max Jacobson, a German immigrant practicing in New York. ${ }^{45,70}$ Jacobson, whose patients nicknamed him "Dr. Feelgood," injected then-Senator Kennedy for the first time in the summer of 1960 with his "vitamin cocktail" that included amphetamine derivatives. ${ }^{4,45}$ Kennedy, who received an injection from Jacobson shortly before the first and pivotal famous televised debate with Richard Nixon, was elected president of the US on November 8, 1960, in a closely contested election..$^{14,45}$

Within several months after taking office Kennedy injured his back during a ceremonial tree-planting incident in Ottawa, Canada, in May 1961. Over the ensuing summer JFK's "physical condition was at its worst point in years. Not for a long time had he been in such agony." 58 This prompted a return to frequent use of crutches, procaine injections, his corset brace, $, 10,14,58$ and an increase in the illicit injections from Jacobson. ${ }^{45}$ The poor state of his back and its effect on JFK's overall well-being may have had a considerable and negative impact on the President's performance at the crucial Vienna summit with Soviet Premier Nikita Khrushchev in June 1961. In fact, on the 1st day of the tense summit the president received at least 3 of the methamphetamine-containing shots. ${ }^{27,45}$ Reeling from the nerve-wracking summit, his aching back, and the likely side effects of Jacobson's methamphetamine shots, the "very gloomy" Kennedy admitted immediately after it ended that the summit did not go well-reflecting that Khrushchev "just beat the hell out of me." $13,45,62,67$ The rest of the summer would provide no respite from his debilitating back pain and would prompt a reassessment of the care administered by Dr. Travell.

\section{Fall 1961 to Summer 1963: Burkley, Kraus, and a Ban on Procaine Injections}

Deeply concerned about the overall condition of Kennedy's back and the increasing use of Travell's procaine shots, Rear Admiral George C. Burkley (a White House physician since Eisenhower's administration) informally took over the responsibility of ministering to JFK's overall health in the summer and fall of 1961 and consulted noted orthopedist and physiatrist Hans Kraus to evaluate the state of the president's back.9,14,58,62 The Austrianborn Dr. Kraus first evaluated the president in October of 1961 and found him "completely unrehabilitated." 58 Kraus and Burkley then placed Kennedy on an exercise and rehabilitation program built around the White House pool and gym. ${ }^{58,62}$ The program consisted of a combination of thrice-weekly weight-lifting sessions and near-daily swims, along with massage and heat therapy ${ }^{14}$ - and paid immediate dividends. Within months, the improvement was dramatic. ${ }^{8,29,58}$

\section{JFK's Lumbar Spine: Radiographic Perspective}

Kennedy's radiographs, many of which are housed at the JFK Presidential Library and Museum, do not support the claim that JFK was born with an unstable lumbosacral joint as diagnosed by Haggart ${ }^{29}$ or the assertion by JFK biographer and historian Robert Dallek that Kennedy suffered from a steroid-induced compression fracture. ${ }^{14}$ Based on our review of the radiographs, there is no evidence for spondylolysis, spondylolisthesis, or congenital lack of lumbar lordosis. Probably consequent to his L5-S1 discectomy surgery in 1944, radiographs did show progressive loss of height of the L5-S1 intervertebral disc space by the time of his 1954 lumbosacral instrumentation and fusion operation. The best-quality radiographs from the end of the president's life are dated March 14, 1962, and show no evidence of the aforementioned compression fractures or coronal deformity or listhesis. They do, however, demonstrate neural foraminal narrowing at L5-S1 and nearcomplete loss of lumbar lordosis, which was not evident on films from 18 years prior. These films also demonstrate some evidence of fusion of the L5-S1 facet joints bilaterally, indicating that the 1954 operation was successful in producing at least some degree of radiographic fusion. Unfortunately, none of his lateral films include the femoral heads or his entire spinal column, which would allow for more precise assessment of global sagittal alignment and spinopelvic parameters.

\section{Summer and Fall of 1963: Did a Relapse of Back Pain Contribute to Kennedy's Death?}

As the condition of Kennedy's back continued to improve, Kraus sought to wean the president from the longtime use of his corset as early as the summer of 1962. ${ }^{29}$ Kraus encountered a setback in his quest to break Kennedy's reliance on his use of back orthotics on August 31, 1963, when a new round of discomfort was diagnosed by Preston Wade as a left iliopsoas strain. Wade advised "heat, rest ... and the application of an Ace bandage spica," ${ }^{30}$ which was similar to, if not the same, Ace bandage used to augment the president's regular canvas corsetboth of which were cut off of JFK during the resuscitation attempts at Parkland Hospital.

Some minor setbacks notwithstanding, it is clear that the period beginning in the fall of 1961 that defines Hans Kraus's management of Kennedy's back problems ushered in a period of sustained and remarkable improvement in the health of JFK's back. Dave Powers, special assistant to the president and a close friend, wrote about meeting with the president in the Oval Office the morning of November 21, 1963, prior to his departure to Texas. Powers recalled "he looked taller than his six feet" and had "the build of a light heavyweight boxer." ${ }^{61}$ The iliopsoas strain experienced by Kennedy in August 1963 and, consequently, the more stringent use of the brace and its augmentation with the Ace bandage thereafter may have played an ominous role in the events of the following day.

It has been theorized by Dr. John Lattimer, a wellpublished physician expert on the Kennedy assassination and the first nongovernmental official to review highly restricted materials such as autopsy photographs, radiographs, clothing, and other materials housed at the National Archives, ${ }^{34-42}$ that the use of this tightly bound lumbar 
brace returned the president to an upright position after the potentially survivable first shot and back into Lee Harvey Oswald's scope sight, allowing the second obviously fatal shot to the head. Had the president not been wearing the augmented brace, he might have crumpled forward and remained out of Oswald's line of fire. . $6,37,42^{2}$

While books and articles exploring the seemingly limitless controversies surrounding President Kennedy's death abound in the popular press, a wealth of excellent articles also exists within the medical literature that address many aspects of the assassination. $3,6-8,34-42,46,48,54,68$ Several salient points bear review in regard to the brace's role and contribution to the president's death. It is by no means assured that President Kennedy could have survived the initial neck wound..$^{35,37,42}$ Kennedy probably would have faced an uphill battle for survival even without the obviously fatal brain wound, because his chronic corticosteroid use would have conferred a reduced capacity to fight a potential infection of the neck and mediastinum that might have been triggered by the first bullet's path. ${ }^{42}$

Another point of controversy concerns the ability of his brace to promote an upright posture after the first bullet struck Kennedy. Dr. Pepper Jenkins, then the chief of the Anesthesiology Department at Parkland Hospital and present during the attempted resuscitation of the president, describes the brace on the day of the assassination: "He was tightly laced into this brace with wide Ace bandages making figure-of-eight loops around his trunk and around his thighs." 7 Robert Hart, a contemporary orthopedic spine specialist, stated in his 2005 article on $\mathrm{JFK}^{26}$ that he remains unconvinced that the brace played a significant role in Kennedy's death. Nevertheless, it is certainly well within the realm of possibility that Kennedy's augmented canvas corset that was bound tightly around the president's hips and lower back could have played a role in setting up Oswald's final shot.

Ultimately, it's impossible to know with certainty how significant a role the brace played in JFK's death on November 22, 1963. Either way, President Kennedy's decision to continue wearing the brace against Hans Kraus's advice shortly before his death is a fascinating and evocative footnote given its potential role in altering the course of US and world history, and serves as yet another unanswered question surrounding that fateful day.

\section{Conclusions}

John F. Kennedy, despite the public image of youthful vitality he and his family so carefully crafted and protected during his lifetime, was afflicted by a litany of serious illnesses.

The etiology of Kennedy's low-back pain, in our opinion, was probably multifactorial in origin, with symptoms of mechanical low-back pain, sacroiliac joint disease, and lumbar radiculopathy leading to many attempts at conservative therapy and multiple failed spinal surgeries including a fusion procedure-an unfortunate pattern of treatment and outcomes that contemporary spine surgeons continue to struggle with at times in a small subset of patients. Another curious footnote to JFK's spine treatment introduces the potential problem of "VIP care" as well-the decision to perform an air myelogram instead of the more accurate but riskier Pantopaque myelogram, which ultimately did little to resolve the question of a herniated disc prior to his unsuccessful discectomy procedure. Ultimately, Kennedy's symptoms and progression of care echo a refrain similar to those of patients who are ultimately diagnosed as suffering from failed-back surgery syndrome.

Personally, JFK remains a case study in the complexity of human nature-an affluent political scion turned war hero, a serial philanderer and methamphetamine user, a civil-rights supporter and initiator of the Vietnam War who was both the youngest man elected president in the nation's history and perhaps the 20th century's least healthy one. His 1000 days in office encompassed a challenging period filled with civil unrest and the haunting specter of nuclear war. Unbeknownst to the general public, Kennedy faced these external challenges while also battling the internal challenge of back pain that was all too often debilitating, and he relied on a near-daily therapy regimen, at times using various combinations of exercise, massage, procaine injections, support orthotics, crutches, narcotics, and illicit intravenous injections of methamphetamines in an attempt to manage this pain. By virtue of a relapse of pain in August of 1963 prompting more frequent use of an augmented brace, back pain may have ultimately played a role in President Kennedy's death.

Despite the chronic pain and sometimes less than admirable measures used in the treatment of the pain, Kennedy repeatedly demonstrated a commendable inclination toward stoicism and bravery highlighted most famously in the PT-109 incident-an incident that made him a decorated World War II hero and helped launch his political career. His exploits not only in the Pacific but generally, in living a life of extraordinary achievement in the face of chronic pain, speak to the power of tenacity and the resilience innate to his character.

After the assassination, Robert F. Kennedy summarized his brother's resolute attitude toward his health: "At least one half of the days that he spent on this earth were days of intense physical pain ... I never heard him complain. I never heard him say anything that would indicate that he felt God had dealt with him unjustly. Those who know him well would know he was suffering only because his face was a little whiter, the lines around his eyes were a little deeper, his words a little sharper. Those who did not know him well detected nothing." 51

\section{Acknowledgments}

We express our gratitude to US Representative French Hill, 2nd District of Arkansas, for his contributions in his role of expediting our approval as research fellows at the John F. Kennedy Presidential Library and Museum in Boston, MA. We thank the members of the John F. Kennedy Presidential Library in Boston for their kindness and assistance: Laurie Austin, Stephen Plotkin, Aubrey Butts, and Kyla Ryan. We also thank Joan Golembiewski of the American Academy of Orthopedic Surgeons for her assistance with figures of the Wilson plate. We appreciate David B. Levine, MD, Weill Cornell Medical Center and Hospital for Special Surgery in New York, for his help and assistance. 


\section{References}

1. Altman LK, Purdum TS: In J.F.K. file, hidden illness, pain and pills. New York Times. November 17, 2002 (http://www. nytimes.com/2002/11/17/us/in-jfk-file-hidden-illness-painand-pills.html) [Accessed March 3, 2017]

2. Anderson C: These Few Precious Days. New York: Gallery Books, 2013, p 44

3. Artwohl RR: JFK's assassination. Conspiracy, forensic science, and common sense. JAMA 269:1540-1543, 1993

4. Beschloss M: The Crisis Years: Kennedy and Khrushchev, 1960-1963. New York: Harper Collins, 1991, pp 189-191

5. Blair J, Blair C Jr: The Search for JFK. New York: Berkley, 1976

6. Breo DL: JFK's death-the plain truth from the MDs who did the autopsy. JAMA 267:2794-2803, 1992

7. Breo DL: JFK's death, Part II-Dallas MDs recall their memories. JAMA 267:2804-2807, 1992

8. Breo DL: JFK's death, Part III-Dr Finck speaks out: 'two bullets, from the rear'. JAMA 268:1748-1754, 1992

9. Burkley GG: George Burkley oral history interview, December 3, 1968, by T. H. Baker. Lyndon B. Johnson Presidential Library, Austin, TX

10. Burkley GG: George G. Burkley oral history interview, JFK Oral History Collection, John F. Kennedy Presidential Library, Boston (https://www.jfklibrary.org/Asset-Viewer/ Archives/JFKOH-GGB-01.aspx) [Accessed March 17, 2017]

11. Cloherty P: Peter Cloherty oral history interview, JFK Oral History Collection, John F. Kennedy Presidential Library, Boston (https://www.jfklibrary.org/Asset-Viewer/ Archives/JFKOH-PJC-01.aspx) [Accessed March 17, 2017]

12. Cobey MC: The value of the Wilson plate in spinal fusion. Clin Orthop Relat Res 76:138-140, 1971

13. Dallek R: The medical ordeals of JFK. Atlantic 290:49-61, 2002

14. Dallek R: An Unfinished Life: John F. Kennedy, 19171963. New York: Little, Brown, \& Co, 2003

15. Donovan R: PT 109: John F. Kennedy in World War II. New York: McGraw-Hill, 1961, pp 106-190

16. Fager CA: James L. Poppen, M.D., 1903-1978. J Neurosurg 51:2-4, 1979

17. Fay PB Jr: The Pleasure of His Company. New York: Harper \& Row, 1966, p 172

18. Ghormley RK: The operative treatment of painful conditions of the lower part of the back. Proc Staff Meet Mayo Clin 6:112-113, 1931

19. Ghormley RK: The study of 100 cases of back pain. Proc Staff Meet Mayo Clin 5:350-351, 1930

20. Gilbert RE: The Mortal Presidency. New York: Fordham University Press, 1998, pp 147-148

21. Goodwin DK: The Fitzgeralds and the Kennedys: An American Saga. New York: Simon \& Schuster, 1987, pp 309-312, 505, 654-657, 774

22. Haggart GE: Early operation (spine fusion) in unstable lumbosacral joints. JAMA 115:2129-2132, 1940

23. Haggart GE: Sciatic pain of unknown origin: an effective method of treatment. J Bone Joint Surg Am 20:851-859, 1938

24. Hamilton N: JFK: Reckless Youth. New York: Random House, 1992

25. Harllee J: John Harllee oral history interview, JFK Oral History Collection, John F. Kennedy Presidential Library, Boston (https://www.jfklibrary.org/Asset-Viewer/ Archives/JFKOH-JH-01.aspx) [Accessed March 17, 2017]

26. Hart RA: Failed spine surgery syndrome in the life and career of John Fitzgerald Kennedy. J Bone Joint Surg Am 88:1141-1148, 2006

27. Hersh S: The Dark Side of Camelot. Boston: Little, Brown, \& Co, 1997, pp 236-237
28. Kennedy JF: Historic Conversations on Life with John F. Kennedy. New York: Hyperion, 2011, pp 15-21

29. Kennedy JF: John F. Kennedy Medical Records, Personal Papers, Box 11A, John F. Kennedy Presidential Library, Boston (https://www.jfklibrary.org/Asset-Viewer/Archives/ JFKPP.aspx?f=1) [Accessed March 17, 2017]

30. Kennedy JF: John F. Kennedy Personal Papers, Box 48, George G. Burkley Files, John F. Kennedy Presidential Library, Boston (https://www.jfklibrary.org/Asset-Viewer/ Archives/JFKPP.aspx?f=1) [Accessed March 17, 2017]

31. Kennedy JP: Joseph P. Kennedy Personal Papers, Box 21. John F. Kennedy Presidential Library, Boston (https:// www.jfklibrary.org/Asset-Viewer/Archives/JPKPP.aspx?f=1) [Accessed March 17, 2017]

32. Kennedy RF: Times to Remember. New York: Doubleday, 1974, pp 84, 93, 215

33. Koskoff DE: Joseph P. Kennedy: A Life and Times. Englewood Cliffs, NJ: Prentice-Hall, 1974, pp 85, 215

34. Lattimer G, Lattimer JK, Lattimer J: The Kennedy-Connally one bullet theory: further circumstantial and experimental evidence. Med Times 102:33-56, 1974

35. Lattimer JK: Additional data on the shooting of President Kennedy. JAMA 269:1544-1547, 1993

36. Lattimer JK: Factors in the death of President Kennedy. JAMA 198:327-333, 1966

37. Lattimer JK: Observations based on a review of the autopsy photographs, X-rays, and related materials of the late President John F. Kennedy. Med Times 100:33-64, 1972

38. Lattimer JK, Laidlaw A, Heneghan P, Haubner EJ: Experimental duplication of the important physical evidence of the lapel bulge of the jacket worn by Governor Connally when bullet 399 went through him. J Am Coll Surg 178:517-522, 1994

39. Lattimer JK, Lattimer G, Lattimer J: Could Oswald have shot President Kennedy? Further ballistic studies. Bull N Y Acad Med 48:513-524, 1972

40. Lattimer JK, Lattimer J: The Kennedy-Connally single bullet theory. A feasibility study. Int Surg 50:524-532, 1968

41. Lattimer JK, Lattimer J, Lattimer G: An experimental study of the backward movement of President Kennedy's head. Surg Gynecol Obstet 142:246-254, 1976

42. Lattimer JK, Schlesinger EB, Merritt HH: President Kennedy's spine hit by first bullet. Bull N Y Acad Med 53:280291, 1977

43. Leaming B: Jacqueline Bouvier Kennedy Onassis: The Untold Story. New York: Thomas Dunne Books, 2014, pp 55-73

44 Lee RL: Robert L. Lee oral history interview, JFK Oral History Collection, John F. Kennedy Presidential Library, Boston (https://www.jfklibrary.org/Asset-Viewer/ Archives/JFKOH-RLL-01.aspx) [Accessed March 17, 2017]

45. Lertzman RA, Birnes WJ: Dr. Feelgood. New York: Skyhorse, 2013, pp 8-9, 13, 18, 91-103

46. Levy ML, Sullivan D, Faccio R, Grossman RG: A neuroforensic analysis of the wounds of President John F. Kennedy: Part 2-a study of the available evidence, eyewitness correlations, analysis, and conclusions. Neurosurgery 54:12981312, 2004

47. Lincoln E: My Twelve Years with John F. Kennedy. New York: McKay, 1965, pp 53-56

48. Lundberg GD: Closing the case in JAMA on the John F. Kennedy autopsy. JAMA 268:1736-1738, 1992

49. MacMahon EB, Curry L: Medical Cover-Ups in the White House. Washington DC: Farragut, 1987, pp 124-125

50. Manchester WR: Portrait of a President. John F. Kennedy in Profile. New York: Little, Brown, \& Co, 1962, p 154

51. Meyers J (ed): John Fitzgerald Kennedy: As We Remember Him. New York: Atheneum, 1965, pp vi, 40-44

52. Mulkern RJ: Robert J. "Patsy" Mulkern oral history interview. JFK Oral History Collection, John F. Kennedy 
Presidential Library, Boston (https://www.jfklibrary.org/ Asset-Viewer/Archives/JFKOH-PJM-01.aspx) [Accessed March 17, 2017]

53. Nicholas JA, Burstein CL, Umberger CJ, Wilson PD: Management of adrenocortical insufficiency during surgery. AMA Arch Surg 71:737-742, 1955

54. Nichols J: President Kennedy's adrenals. JAMA 201:115116,1967

55. O’Brien M: John F. Kennedy: A Biography. New York: Thomas Dunne Books, 2005, p 127

56. O' Donnell KP, Powers DF: Johnny, We Hardly Knew Ye. Boston: Little, Brown, \& Co, 1970, pp 79, 96

57. Parmet H: Jack: The Struggles of John F. Kennedy. Norwalk, CT: Easton Press, 1986, pp 15-17, 308-315

58. Parmet H: JFK: The Presidency of John F. Kennedy. Norwalk, CT: Easton Press, 1986, pp 118-119

59. Pitts D: Jack and Lem. New York: Carroll \& Graf, 2007, p 148

60. Platt H: Philip Duncan Wilson, M.D. 1886-1969. J Bone Joint Surg Am 51:1445-1450, 1969

61. Powers DF: David F. Powers Personal Papers, Box 15, John F. Kennedy Presidential Library, Boston (https://www. jfklibrary.org/Asset-Viewer/Archives/DFPPP.aspx) [Accessed March 17, 2017]

62. Reeves R: President Kennedy: Profile of Power. New York: Simon \& Schuster, 1993, pp 42-43, 146-147, 242-244

63. Schlesinger AM Jr: A Thousand Days. John F. Kennedy in the White House. Boston: Houghton Mifflin, 1965, p 95

64. Simons DG: Cardiology and myofascial trigger points: Janet G. Travell's contribution. Tex Heart Inst J 30:3-7, 2003

65. Sorenson TC: Kennedy. New York: Harper \& Row, 1965, p 40

66. Stanford Daily: National lottery draws names of 24 Stanford men, two professors. Stanford Daily, October 30, 1940; 1

67. Stoughton C, Clifton CV, Sidey H: The Memories. JFK 1961-1963. New York: WW Norton, 1980, p 7

68. Sullivan D, Faccio R, Levy ML, Grossman RG: The assassination of President John F Kennedy: a neuroforensic analysis-part 1: a neurosurgeon's previously undocumented eyewitness account of the events of November 22, 1963. Neurosurgery 53:1019-1027, 2003
69. Travell J: Janet Travell oral history interview. JFK Oral History Collection, John F. Kennedy Presidential Library, Boston (https://www.jfklibrary.org/Asset-Viewer/ Archives/JFKOH-JGT-01.aspx) [Accessed March 17, 2017]

70. Travell J: Office Hours: Day and Night. The Autobiography of Janet Travell, M.D. New York: World Publishing, 1968, pp 312, 320, 322, 358

71. Valentino V: Myelography. Springfield, IL: Charles C Thomas, 1965 , pp 3-4

72. Warwick MH, Parkes AS: Absorption of progesterone and desoxcorticosterone: from tablets implanted subcutaneously. Lancet 235:406-408, 1940

73. Wilson PD, Straub LR: Lumbosacral fusion with metallic plate fixation. Instr Course Lect 9:52-57, 1952

\section{Disclosures}

The authors report no conflict of interest concerning the materials or methods used in this study or the findings specified in this paper.

\section{Author Contributions}

Conception and design: both authors. Acquisition of data: both authors. Analysis and interpretation of data: both authors. Drafting the article: both authors. Critically revising the article: both authors. Reviewed submitted version of manuscript: both authors. Approved the final version of the manuscript on behalf of both authors: Dowdy. Administrative/technical/material support: both authors. Study supervision: both authors.

\section{Supplemental Information}

\section{Previous Presentations}

Portions of this work were presented in oral form at the 2014 American Association of Neurological Surgeons Annual Meeting on April 9, 2014, in San Francisco, CA.

\section{Correspondence}

Justin Dowdy, Hot Springs Neurosurgery Clinic, 1 Mercy Lane, Ste. 502, Hot Springs, AR 71913. email: jdowdymd@gmail.com. 